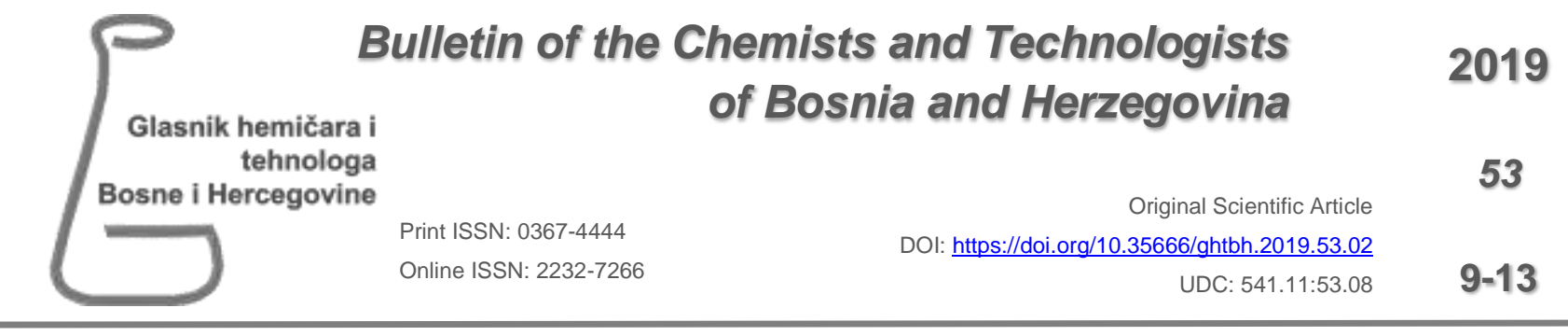

\title{
Calibration bath uncertainty in precision temperature measurements
}

\author{
Đekić, M. ${ }^{\text {a }}$, Brkić, I. ${ }^{\text {a }}$, Hodžić, N. ${ }^{\text {b }}$, Čohodarević, S. ${ }^{\text {b }}$ \\ ${ }^{\mathrm{a}}$ Faculty od Science, Zmaja od Bosne 33-35, 71000 Sarajevo, Bosnia and Herzegovina \\ ${ }^{\mathrm{b}}$ Institute of Metrology of Bosnia and Herzegovina, Augusta Brauna 2, 71000 Sarajevo, Bosnia and Herzegovina
}

Article info

Received: 11/04/2019

Accepted: 07/10/2019

Keywords:

Calibration bath

Homogeneity

Stability

Uncertainty

\begin{abstract}
Calibration baths are widely used in many laboratories worldwide for the calibration of thermometers by comparison. They come in different shapes and sizes and use different media (water, alcohol, silicon oil etc.), but a certain nonuniformity of the used media is always present. During precision temperature measurements, uniformity (homogeneity and temporal stability) of a calibration bath is of the utmost importance since its contribution to total measurement uncertainty is the largest. The temperature gradient can be described as a change of temperature at different positions inside the bath working volume. Temporal temperature stability depends on many factors such as: the bath temperature, control system, bath construction and the flow of the used media inside the bath, just to name a few. In this paper, we investigate uniformity of a cylindrical calibration bath. Homogeneity is determined by measurement of axial and radial temperature gradient inside the bath. Stability is examined by observation of the change in temperature reading during certain period of time. The obtained results are compared with manufacturer specification and can be used for determination of calibration bath contribution to total measurement uncertainty during calibration of thermometers.
\end{abstract}

*Corresponding author: Maja Đekić

E-mail:majadeki@gmail.com Phone: 00 387-33-279- 891 bath in the range from $-80{ }^{\circ} \mathrm{C}$ to $300{ }^{\circ} \mathrm{C}$. For calibration by comparison method, a minimum of two thermometers is needed, i.e. a reference thermometer and a thermometer to be calibrated.

There are several uncertainty sources in the process of calibration of thermometers by comparison. Some of them can be determined from calibration certificates of the used equipment, but some have to be measured or estimated (Bojkovski, Batagelj, Drnovšek, et al., 2009; Drnovšek, Puškin and Bojkovski, 1999). A major contribution to overall uncertainty during calibration of thermometers by comparison comes from a calibration bath (Bojkovski, Batagelj, Drnovšek, et al., 2009; Drnovšek, Puškin and Bojkovski, 1999; Pušnik, Drnovšek and Bojkovski, 1998). To calculate uncertainty of the calibration bath it is necessary to investigate its uniformity, since calibration bath cannot be considered to be completely stable with time nor homogeneous all over its volume. In order to decrease this uncertainty contribution, equalizing blocks with
The measurements for calibration of thermometers by comparison are usually performed inside a calibration 
holes for positioning thermometers inside of the calibration bath can be used (Bojkovski, Batagelj, Drnovšek, et al., 2009).

\section{EXPERIMENTAL}

The experiment described in this paper was conducted with the aim of investigating uniformity of a cylindrical calibration bath and its uncertainty contribution to the total calibration uncertainty. We used the Parallel Tube Liquid Bath Model 915 (Isothermal Technology) with an equalizing block inside, as presented in Figure 1.

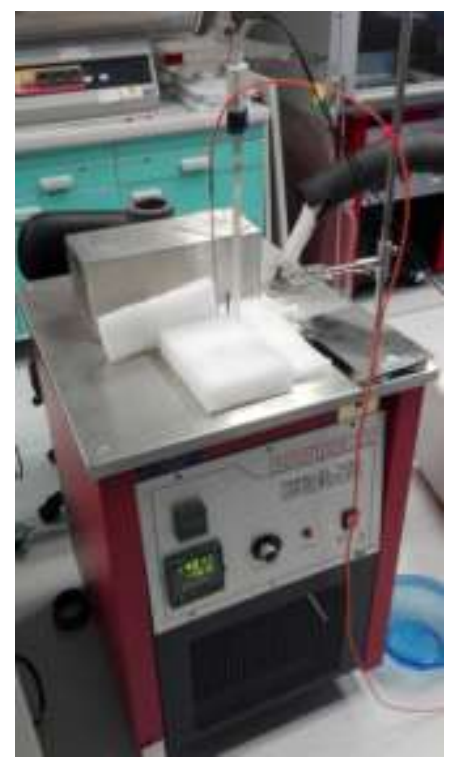

Figure 1: Parallel Tube Liquid Bath Model 915 (Isothermal Technology)

The bath working volume is $3017 \mathrm{~cm}^{3}$, while its liquid capacity is approximately $7 \mathrm{l}$. The equalizing block contains four bores with diameter of $8 \mathrm{~mm}$ and depth of $120 \mathrm{~mm}$, in which temperature sensors can be placed. Both, the fixed and the mobile thermometer were standard platinum resistance thermometers SPRT 159 and SPRT 154 model 670SQ respectively (Isothermal Technology).

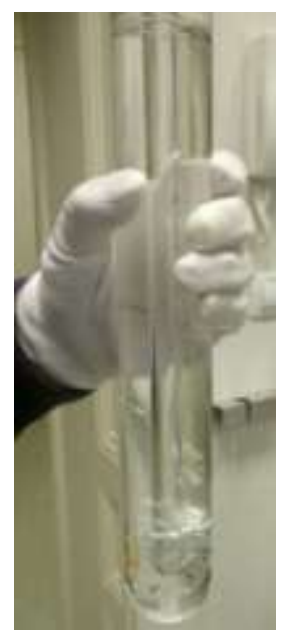

Figure 2: A water triple point cell (WTP)
Radial gradient was measured with both thermometers fixed at the maximum depth. In order to determine axial gradient, the reference thermometer was fixed at a maximum depth while the mobile thermometer was moved axially in steps of $2 \mathrm{~cm}$ inside the equalizing block of the calibration bath. Thermometry bridge Fluke 1594A (Fluke Calibration) was used for simultaneous measurements on both thermometers since it provides possibility of data storage. Temporal stability was examined by monitoring the change in the reference thermometer reading during 20 minutes. A water triple point cell (WTP), presented in Figure 2, was realized with dry ice method, and it was used for checking the stability of the reference thermometer. In order to investigate homogeneity of the calibration bath, radial and axial gradient were calculated (Drnovšek, Bojkovski and Pušnik 1997; Drnovšek, Bojkovski and Pušnik 2000). We conducted 10 measurements at three different temperatures with three different media as follows: at $40{ }^{\circ} \mathrm{C}$ we used ethanol, at $50{ }^{\circ} \mathrm{C}$ we used distilled water and at $150{ }^{\circ} \mathrm{C}$ we used oil. Environmental air temperature and humidity, recorded during the measurements, were as follows: $21,3{ }^{\circ} \mathrm{C}$ and $34 \%, 22,4$ ${ }^{\circ} \mathrm{C}$ and $43 \%$ and $22,4{ }^{\circ} \mathrm{C}$ and $54 \%$ respectively. The coverage factor or probability level for all the equations in this paper is $k=1$. Uncertainty contribution caused by the radial gradient $\mathrm{g}_{\mathrm{r}}$ can be calculated using following equation

$$
g_{r}=\frac{1}{\sqrt{3}} \max \left|t_{r, i}-t_{m, i}\right|=\frac{1}{\sqrt{3}} \max \Delta t ; i=1 \text { to } n
$$

where $n$ is the number of measurements, $t_{r, i}$ and $t_{m, i}$ are temperature readings of the reference thermometer and of the mobile thermometer respectively. The gradient represents maximum temperature difference $\max \Delta t$ between the reference thermometer and the mobile thermometer when both of them are at the maximum depth. In general, the axial gradients $g_{a}$ can be derived by calculating the maximum change in temperature difference registered between the reference and the mobile thermometer (maximum registered at any two positions of the mobile thermometer).

The homogeneity caused by both gradients is determined from the formula:

$$
h=\sqrt{g_{r}^{2}+g_{a}^{2}}
$$

During stability investigation, the change in the reference thermometer reading was observed for 20 minutes. Maximum difference between the observed temperatures is used for stability determination as follows

$$
s=\frac{1}{2 \sqrt{3}}\left|t_{r, \max }-t_{r, \min }\right|
$$

Total measurement uncertainty contribution of the calibration bath due to gradients and temporal stability is calculated from

$$
u_{b a t h}=\sqrt{h^{2}+s^{2}}
$$




\section{RESULTS AND DISCUSSION}

In order to calculate the contribution of the measurement uncertainty of the bath, we determined its radial gradient, axial gradient and temporal stability. The results of the radial gradient measurements are presented in Figure 3, as differences in temperature readings between the reference and the mobile thermometer. We can notice small variations in temperature, of order $10^{-3}$ ${ }^{\circ} \mathrm{C}$.

Axial gradient inside the calibration bath at three different temperatures is presented in Figure 4, as a difference in temperature reading of the reference thermometer and the mobile thermometer. The results also show small temperature variations, of order $10^{-3}{ }^{\circ} \mathrm{C}$.
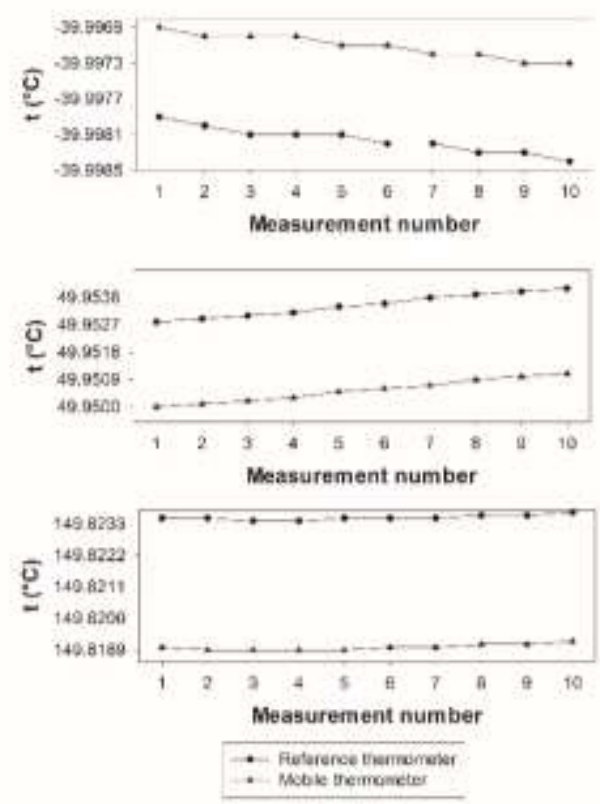

Figure 3: The radial gradient inside a calibration bath at $-40{ }^{\circ} \mathrm{C}, 50$ ${ }^{\circ} \mathrm{C}$ and $150^{\circ} \mathrm{C}$ respectively. Lines are just guide for the eye.

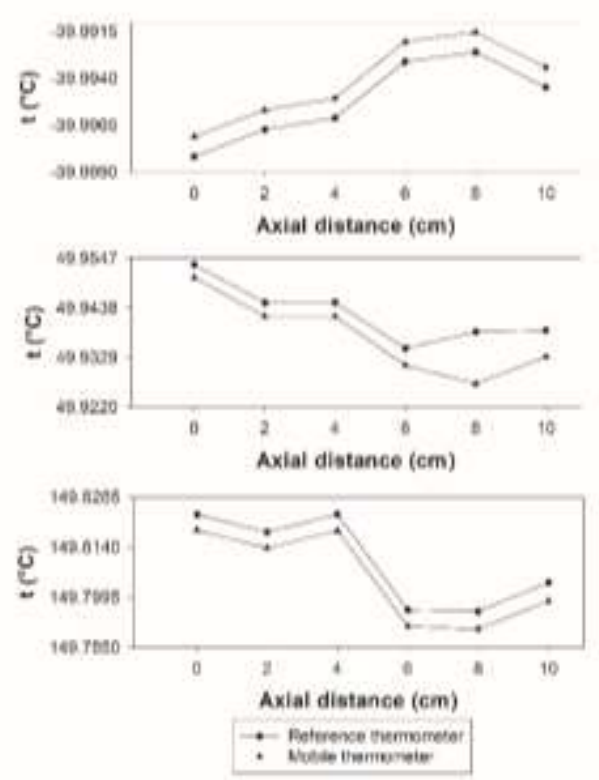

Figure 4: The axial gradient inside the calibration bath at $-40{ }^{\circ} \mathrm{C}$, $50{ }^{\circ} \mathrm{C}$ and $150{ }^{\circ} \mathrm{C}$ respectively. The lines are just a guide for the eye.
The stability of the calibration bath at three different temperatures is presented in Figure 5. As before, we can notice small temperature variations of the reference thermometer readings over time.
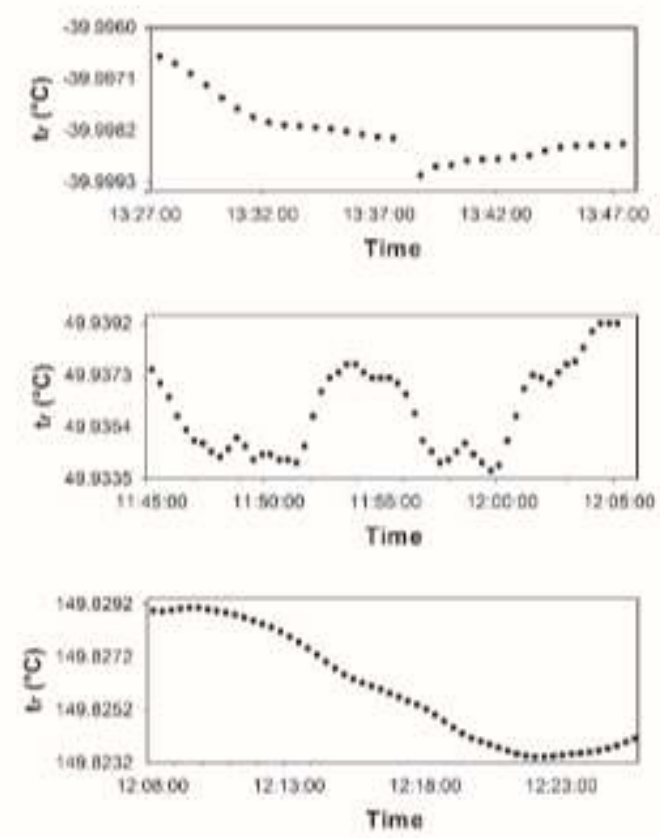

Figure 5: Temporal stability of the calibration bath at $-40{ }^{\circ} \mathrm{C}, 50$ ${ }^{\circ} \mathrm{C}$ and $150{ }^{\circ} \mathrm{C}$ respectively.

Homogeneity caused by axial and radial gradient, stability and uncertainty of the bath were calculated from (2), (3) and (4) respectively. The results are presented in Table 1.

Table 1: Radial $g_{r}$ and axial $g_{a}$ gradients, homogeneity h, stability $\mathrm{s}$ and total uncertainty of the bath $\mathrm{u}_{\text {bath }}$ at three different temperatures.

\begin{tabular}{|c|c|c|c|c|c|}
\hline $\mathrm{T}\left({ }^{\circ} \mathrm{C}\right)$ & $g_{r}\left({ }^{\circ} \mathrm{C}\right)$ & $g_{a}\left({ }^{\circ} \mathrm{C}\right)$ & $h\left({ }^{\circ} \mathrm{C}\right)$ & $\left({ }^{\circ} \mathrm{C}\right)$ & $\mathrm{u}_{\text {bath }}\left({ }^{\circ} \mathrm{C}\right)$ \\
\hline & & & & & \\
\hline 5 & & & & & \\
\hline 150 & -0. & .0 & 0.00 & \pm 0 & +0 \\
\hline
\end{tabular}

Our results show that uncertainty slightly increases with temperature. However, we cannot compare these values, since measurements were taken with different media. We stipulate that one of the reasons for the bath to be the most stable at $-40{ }^{\circ} \mathrm{C}$ could be caused by the fact that it was left at that temperature overnight and the calibration bath probably reached better stability before the beginning of the measurements.

Manufacturer specification (IsoTech, Parallel Tube Liquid Bath Model 915; IsoTech, Evaluation Report Parallel Tube Liquid Bath:Model 915) contained relevant information of temporal stability of the calibration bath with water, oil and methanol, which enabled us to compare these data with our results as presented in Table 2. We can notice that measured stability values are smaller than those provided by the manufacturer. However, these values cannot be directly 
compared since the measurements were taken at different temperatures from those in the manufacturer specification. In addition, stability at the lowest temperature depends on the type of media that was used.

Table 2: Stability of the calibration bath obtained from the measurements $\mathrm{s}_{\mathrm{m}}$ and the stability from the manufacturer specification $\mathrm{s}_{\mathrm{s}}$

\begin{tabular}{cccccc}
\hline $\mathrm{T}\left({ }^{\circ} \mathrm{C}\right)$ & Medium & $\mathrm{s}_{\mathrm{m}}\left({ }^{\circ} \mathrm{C}\right)$ & $\mathrm{T}\left({ }^{\circ} \mathrm{C}\right)$ & Medium & $\mathrm{s}_{\mathrm{s}}\left({ }^{\circ} \mathrm{C}\right)$ \\
\hline-40 & Ethanol & \pm 0.001 & -65 & Methanol \pm 0.005 \\
50 & Water & \pm 0.002 & 35 & Water & \pm 0.004 \\
150 & Silicon oil \pm 0.002 & 125 & Silicon oil \pm 0.007
\end{tabular}

Total uncertainty stipulated by the manufacturer was compared with measured uncertainty for two different media as presented in Table 3. For that purpose, our results were rounded to three decimal places.

Table 3: Calibration bath uncertainty obtained from the measurements $\mathrm{u}_{\mathrm{bathm}}$ and the uncertainty from the manufacturer specification $\mathrm{u}_{\text {baths }}$

\begin{tabular}{cccccc}
\hline $\mathrm{T}\left({ }^{\circ} \mathrm{C}\right)$ & Medium & $\mathrm{u}_{\text {bathm }}\left({ }^{\circ} \mathrm{C}\right)$ & $\mathrm{T}\left({ }^{\circ} \mathrm{C}\right)$ & Medium & $\mathrm{u}_{\text {baths }}\left({ }^{\circ} \mathrm{C}\right)$ \\
\hline 50 & Water & \pm 0.005 & 50 & Water & \pm 0.004 \\
150 & Silicon oil & \pm 0.005 & 100 & Oil & \pm 0.007
\end{tabular}

The results obtained for water only slightly differ from the manufacturer specification data. Differences for silicon oil are a little bit bigger which can be explained by the fact that the measurements were taken at different temperature. From manufacturer specification we can also notice that uncertainty was smaller for the lower temperature, so the correlation between uncertainty and temperature ought to be further investigated.

\section{CONCLUSIONS}

The conducted investigation of homogeneity and stability of the calibration bath enables us to determine its total uncertainty contribution. This information is crucial for any laboratory dealing with calibration of thermometers by comparison method. On the basis of the calibration laboratories data, one out of five instruments either gives false reading or a possible error is not declared in the manufacturer specification (Nicholas and White 2001).

Our preliminary results indicate that it is advisable to leave the calibration bath at the temperature of measurement overnight in order to achieve better stability before the measurements are conducted. We are planning to verify this conclusion with further investigations for higher temperatures. The amount of uncertainty as determined in our experiment is not very different from the one given in the manufacturer specification, though there are some small differences.
We came to a conclusion that it is justified to determine measurement uncertainty of the calibration bath regardless of manufacturer specification, especially in the laboratories dealing with precise temperature measurements.

This is particularly so since laboratories have different working conditions, use different thermometers or possibly different procedures for determination of stability and/or homogeneity of the calibration bath.

\section{REFERENCES}

Batagelj, V., Bojkovski, J. (2011). Calibration by Comparison of Platinum Resistance Thermometers Using Slow Resistance Bridges. International Journal of Thermophysics, 32 (7-8), 1409-1417.

Bojkovski, J., Batagelj, V., Drnovšek, J., Žužek V. (2009). Practical Limits of Measurement Uncertainties in Calibration of Standard Platinum Resistance Thermometers by Comparison, in Proceedings of XIX IMEKO World Congress Fundamental and Applied Metrology, Lisbon, Portugal, p.p. 1581-1584.

Drnovšek, J., Bojkovski, J., Pušnik, I. (1997). A general procedure for evaluation of calibration baths in precision temperature measurements, in Proceedings of IEEE Instrumentation and Measurement Technology Conference, Ottawa, Canada, IMTC, vol. 2, p.p 1370-1372.

Drnovšek, J., Bojkovski, J., Pušnik, I. (2000). General procedure for uncertainty evaluation of a temperature calibration bath. Instrumentation Science \& Technology, 28 (5), 413-420.

Drnovšek, J., Puškin, I., Bojkovski, J. (1998). Reduction of Uncertainties in Temperature Calibration by Comparison, Measurement Science and Technology 9 (11), 1907-1911.

IsoTech, Parallel Tube Liquid Bath Model 915, Handbook, England, issue 5-11/07.

IsoTech, Evaluation Report Parallel Tube Liquid Bath:Model 915 England, Issue 01/07.

Nicholas, J. V., D.R. White, D. R. (2001). Traceable Temperatures: An Introduction to Temperature Measurement and Calibration ( $2^{\text {nd }}$ Ed.) John Wiley \& Sons, Ltd.

Parali, L., Durmaz, F., Aydin, O. (2018). Calibration of Platinum Resistance Thermometer (Pt-100) and Its Measurement Uncertainty Analysis. Celala Bayar University Journal of Science, 14 (1), 4149.

Pušnik, I., Drnovšek, J., Bojkovski, J. (1998). Lowest Uncertainty Contributions in Temperature Calibrations by Comparison, in Proceedings of IEEE Instrumentation and Measurement Technology Conference, St. Paul, USA, IMTC/98, vol 2, p.p. 1257-1259. 


\section{Summary/Sažetak}

Kalibraciona kupatila se koriste u mnogim laboratorijama širom svijeta za kalibraciju termometara metodom poređenja. Mogu se naći kupatila različitog oblika i veličine i koriste različite medije (voda, alcohol, silikonsko ulje itd.), ali određena neuniformnost unutar medija je uvijek prisutna. Za vrijeme preciznih mjerenja temperature, uniformnost (homogenost $\mathrm{i}$ vremenska stabilnost) kalibracionog kupatila je od najveće važnosti pošto je njen doprinos ukupnoj mjernoj nesigurnosti najveći. Temperaturni gradijent se može opaziti kao promjena u očitanju termometra u skladu sa promjenom njegovog položaja unutar kupatila. Vremenska stabilnost zavisi od protoka korištenog medija unutar kupatila. U ovom radu, ispitaćemo uniformnost cilindričnog kalibracionog kupatila. Homogenost se može odrediti mjerenjem aksijalnog I radijalnog temperaturnog gradijenta unutar kupatila. Stabilnost se može odrediti mjerenjem promjene očitanja termometra u određenom vremenskom intervalu. Dobijeni rezultati se mogu uporediti sa specifikacijom proizvođača i iskoristiti za određivanje doprinosa kalibracionog kupatila ukupnoj mjernoj nesigurnosti tokom kalibracije termometara. 